\title{
ANALISIS KONTRASTIF BAHASA JAWA NGOKO MADIUNAN DAN BAHASA INDONESIA
}

\author{
Aloysius Rangga Aditya Nalendra, Fajar Shidiq, Vina Aisyah Zede \\ Universitas Bina Sarana Informatika \\ Email: rangga280@gmail.com, fajar.fsq@bsi.ac.id, vina.daz@bsi.ac.id
}

\begin{abstract}
Abstrak: Penelitian ini mengkaji perbandingan verba dan nomina hasil proses afiksasi dalam Bahasa Jawa Ngoko (BJ) yang digunakan di daerah Madiun dan Bahasa Indonesia (BI). Dalam analisis perbandingan tersebut digunakan metode analisis kontrastif untuk membandingkan kedua bahasa tersebut. Kridalaksana (2001: 13) menegaskan bahwa analisis kontrastif adalah metode sinkronis dalam menganalisis bahasa untuk menunjukkan persamaan dan perbedaan antara dua bahasa atau dialek untuk mencari pokok yang dapat digunakan untuk masalah sederhana, seperti dalam pengajaran dan penerjemahan bahasa. Analisis data difokuskan pada persamaan dan perbedaan kedua bahasa tersebut. Persamaan bahasa ditemukan pada pembentukan kata kompleks dengan menggunakan afiks. Misalnya kata nakoni (BJ) berimbuhan $n$ - $i$ pada kata takon sejajar dengan pembentukan kata tanya (BI) yang diberi imbuhan me-i menjadi menanyai. Perbedaan penggunaan bahasa Jawa dan bahasa Indonesia, antara lain terjadi pada nomina yang terbentuk dari proses afiksasi $p a$ - yang dalam penerjemahannya membutuhkan kata keterangan berupa frase atau kata yang kompleks karena tidak ada paralelisme dalam Bahasa Indonesia, contohnya pakethik artinya 'orang yang mengambil kuda'. Contoh lain adalah verba yang dibentuk dengan menambahkan prefiks $k e$ - dalam bahasa Jawa yang memiliki alomorf /k/ atau /kek/. Kedua alomorf terjadi jika prefiks $k e$ - bertemu kata dengan fonem vokal, misalnya ke+antem 'pukul' menjadi keantem yang dalam bahasa Indonesia adalah terpukul.
\end{abstract}

Kata Kunci: analisis kontrastif, bahasa Jawa, bahasa Indonesia.

\section{CONTRASTIVE ANALYSIS OF JAVA NGOKO MADIUNAN AND INDONESIAN LANGUAGE}

\begin{abstract}
This study examines the comparison of verbs and nouns resulting from the affixation process in Javanese which is used in the Madiun area and Indonesian. In the comparative analysis, the contrastive analysis method was used to compare the two languages. Kridalaksana (2001: 13) emphasizes that contrastive analysis is a synchronic method of analyzing language to show similarities and differences between two languages or dialects to find a subject that can be used for simple problems, such as in language teaching and translation. Data analysis focused on the similarities and differences between the two languages. Language equations are found in complex word formation using affixes. For example, the word "nakoni" (Javanese) with the affix " $n$ - $i$ " in the word "takon" is parallel to the formation of the word "menanyai" (Indonesia) which is added with the affix "me-i" in Indonesian word "tanya". Differences in the use of Javanese and Indonesian, among others, occur in nouns which are formed from the affixation process of "pa-" which in translation requires an adverb in the form of a complex phrase or word because there is no parallelism in Indonesian, for example "pakethik" means 'person who takes a horse'. Another example is a verb that is formed by adding a prefix to the Javanese language which has the allomorph / k/or / kek/. Both allomorphs occur when the prefix "ke- " meets a word with a vowel phoneme, for example "ke + antem" 'pukul' becomes a "keantem" which in Indonesian is "terpukul".
\end{abstract}

BASASTRA Jurnal Bahasa, Sastra, dan Pengajarannya

Volume 9 Nomor 1, April 2021, P-ISSN 2302-6405, E-ISSN 2714-9765 
Keywords: contrastive analysis, Javanese language, Indonesian language

\section{PENDAHULUAN}

Indonesia terdiri ratusan dialek dan bahasa daerah, hampir 700-an lebih terdapat dialek dan bahasa daerah yang ada di dalam negara Republik Indonesia ini (Kemendikbud, 2019). Dengan keragaman tersebut, umumnya bahasa daerah menjadi sebagai bahasa utama sedangkan bahasa Indonesia menjadi bahasa kedua. Fenomena bahasa ini berkembang karena Indonesia merupakan negara terkenal yang memiliki beragam budaya dan suku (Ula, dkk., 2020). Dengan kata lain, bahwa budaya menjadi penentu perkembangan sebuah bahasa serta turut menyumbang keragaman bahasa.

Ragam budaya tersebut menghasilkan beragam bahasa yang memperkaya budaya Indonesia. Adanya budaya daerah menghasilkan bahasa daerah yang beragam, sehingga menyebabkan masyarakat menjadi penutur dwibahasa yang dapat berbicara dalam dua bahasa yaitu bahasa daerah sebagai bahasa ibu dan bahasa Indonesia sebagai bahasa nasional. Dengan fakta tersebut, maka tak heran masyarakat Indonesia mampu menjadi penutur dua bahasa yakni bahasa ibu yang merupakan bahasa daerah serta bahasa Indonesia sebagai bahasa nasional (Suharyo, 2018). Hal ini pula terjadi di daerah Madiun. Sebagai sebuah kota di daerah Jawa Timur, Madiun mendapat pengaruh budaya sehingga menciptakan dialek serta bahasa yang berbeda dari kota lainnya (Paryono, 2014). Dengan pengaruh budaya Jawa Timur serta peralihan Yogyakarta-Solo, membuat bahasa Jawa yang digunakan di daerah Madiun menjadi unik sehingga menarik untuk menjadi bahan kajian.

Penelitian ini hendak memaparkan penggunaan bahasa Jawa dan bahasa Indoensia. Dalam penelitian ini, peneliti menjelaskan tentang perbandingan bahasa Jawa ngoko yang dituturkan oleh masyarakat Madiun dan bahasa Indonesia sebagai sumber penelitian. Dalam penelitian ini bahasa Jawa dikaji dengan analisis kontrastif untuk melihat pembentukan kata kerja dan kata benda dalam bahasa Jawa dan bahasa Indoensia. Dengan melakukan metode ini, maka tujuan penelitian ini adalah untuk memaparkan bagaimana pembentukan kata kerja dan kata benda dalam bahasa Jawa ngoko dialek Madiunan dengan membandingkan proses di dalam bahasa Indonesia sehingga hasil penelitian ini dapat menjadi kajian literasi mengenai fenomena dalam bahasa serta pengajaran mengenai keragaman bahasa terutama dalam kajian mengenai bahasa daerah. Berdasarkan dari tujuan tersebut, maka peneliti merumuskan permasalahan dalam penelitian ini adalah bagaimana proses afiksasi verba dan nomina dalam bahasa Jawa Ngoko dialek Madiunan dengan bahasa Indonesia. 
Bahasa Jawa adalah bahasa rumpun bahasa Melayu yang memiliki banyak tingkatan dalam penggunaan bahasa tersebut (Mijianti, 2017). Penggunaan tingkatan berkaitan dengan etika sebagai dasar komunikasi (Hasanah, dkk., 2015). Ada tiga tingkatan, yaitu bahasa ngoko, madya dan krama (Sukarto, 2010). Penelitian ini mengkaji verba dan nomina pembentuk proses afiksasi dalam bahasa Jawa Ngoko sebagai sumber penelitian karena bahasa Jawa Ngoko memiliki kemiripan dengan bahasa Indonesia. Kemiripannya terlihat pada ciri-cirinya, keduanya memiliki fungsi yang sama untuk membentuk kata-kata yang kompleks (Kurniawan, 2013). Contoh hal tersebut dapat dijumpai dalam bahasa Jawa misalnya dalam kata "nakoni" dalam bahasa Jawa (BJ) dilampirkan imbuhan $n-i$ pada kata "takon" dan dalam bahasa Indonesia adalah 'tanya'. Selanjutnya, kata "menanyakan" dalam bahasa Indonesia dilampirkan elemen "me-...- pada kolom "tanya". Selain persamaan tersebut, penelitian ini juga menjelaskan tentang perbedaan penggunaan bahasa Jawa dan bahasa Indonesia seperti pada nomina yang terbentuk dari proses afiksasi "pa-" yang dalam penerjemahannya membutuhkan kata keterangan berupa frase atau kata yang kompleks karena tidak ada paralelisme dalam bahasa Indonesia. Contoh, pangendhang, dari kata gendhang. Namun, karena terdapat imbuhan 'pa-' sehingga kata tersebut tidak memiliki arti dalam bahasa Indonesia sehingga membutuhkan kata keterangan berupa frase atau kata yang kompleks. Contoh lain adalah verba yang dibentuk dengan menambahkan prefiks "ke-" dalam bahasa Jawa yang alomorf $/ \mathrm{k} /$ atau /kek/. Keduanya alomorf terjadi jika prefiks "ke-" memenuhi kata vokal. Misalnya, antem 'pukul' menjadi kantem.

Analisis kontrastif adalah analisis dua bahasa yang berkaitan dengan linguistik, sebagai pengajaran dan terjemahan bahasa (Kusumastuti, 2017). Analisis ini menjelaskan tentang perbedaan struktural kedua bahasa. Selanjutnya perbedaan elemen dianalisis untuk mengetahui penyebab kesalahan bahasa. Secara teori mengatakan bahwa analisis kontrastif adalah kesulitan dalam fonologi dan struktural (Kusumastuti, 2017). Terdapat tingkat kesulitan berdasarkan tiga hubungan antara bahasa pertama (B1) dan bahasa kedua (B2).

Tabel 1. Tingkat Hubungan antara Bahasa Pertama dan Bahasa Kedua

\begin{tabular}{cl}
\hline No & \multicolumn{1}{c}{ Kontrastif } \\
\hline 1 & $\begin{array}{l}\text { B1 memiliki aturan, dan B2 memiliki } \\
\text { perumpamaan }\end{array}$ \\
\hline 2 & $\begin{array}{l}\text { B1 memiliki aturan, tetapi B2 tidak } \\
\text { memiliki perumpamaan }\end{array}$ \\
\hline 3 & $\begin{array}{l}\text { B2 memiliki suatu aturan, dan tidak ada } \\
\text { perumpamaan dalam B1 (Ekapartiwi, } \\
\text { 2009) }\end{array}$ \\
\hline
\end{tabular}

Lebih lanjut, analisis kontrastif yang digunakan untuk istilah anacon 
adalah kegiatan perbandingan dua struktur dua bahasa, yaitu bahasa pertama dan bahasa kedua. Perbedaan dua bahasa tersebut, dari anacon dapat digunakan sebagai dasar untuk memprediksi kesulitan atau kendala dalam pengajaran bahasa yang dihadapi siswa di sekolah dalam mempelajari B2. Dalam proses pengkajian struktur dua bahasa terdapat pendekatan mikrolinguistik yang memiliki empat tingkatan, yaitu:

Tabel 2. Pendekatan Mikrolinguistik

\begin{tabular}{cc}
\hline No. & Pendekatan \\
\hline 1 & Fonologi atau bunyi sistem bahasa \\
\hline 2 & $\begin{array}{l}\text { Leksikon adalah komponen bahasa yang } \\
\text { memuat semua informasi tentang makna } \\
\text { dan penggunaan kata-kata dalam bahasa }\end{array}$ \\
\hline $3 \quad \begin{array}{l}\text { Morfologi adalah aspek pembentuk kata } \\
\text { dalam bahasa. }\end{array}$ \\
Sintaksis adalah susunan kata-kata yang \\
menjadi klausa dan kalimat dalam \\
bahasa (Muhassin, 2014). \\
Selain perbandingan struktur \\
bahasa, analisis kontrastif dapat \\
membandingkan aspek di luar struktur \\
bahasa, misalnya unda usuk 'tingkat \\
tutur'. Misalnya, kata dhahar 'makan' \\
dalam bahasa Jawa memiliki tingkat \\
tutur krama, sedangkan kata dhahar \\
'makan' dalam bahasa Sunda, tutur \\
$\begin{array}{l}\text { ngoko atau kasar. Ada empat hal } \\
\text { penting yang perlu diperhatikan dalam } \\
\text { menganalisis } \\
\text { menggunakan analisis kontrastif. }\end{array}$
\end{tabular}

Tabel 3. Prosedur Analisis

\begin{tabular}{ll}
\hline No. & \multicolumn{1}{c}{ Prosedur Analisis } \\
\hline 1. & $\begin{array}{l}\text { Prosedur analisis kontrastif, merupakan } \\
\text { pembandingan struktur atau sistem dari } \\
\text { dua bahasa. }\end{array}$ \\
\hline 2 & $\begin{array}{l}\text { Analisis kontrastif bertujuan untuk } \\
\text { menunjukkan persamaan dan perbedaan } \\
\text { kedua bahasa (fokus pada perbedaannya). }\end{array}$ \\
\hline 3 & $\begin{array}{l}\text { Observasi analisis ini bisa sinkronis atau } \\
\text { diakronis. }\end{array}$ \\
\hline 4 & $\begin{array}{l}\text { Manfaat analisis kontrastif kedua bahasa } \\
\text { dalam proses pembelajaran bahasa dan } \\
\text { penerjemahan (Sanga, 2008). }\end{array}$ \\
\hline & Aspek analisis kontrastif terdiri
\end{tabular}

dari aspek kebahasaan dan aspek psikologi. Aspek kebahasaan dari aspek kontrastif berkaitan dengan perbandingan struktur dua bahasa untuk menemukan perbedaannya. Di sisi lain, aspek psikologi analisis kontrastif berkaitan dengan langkah kedua, ketiga, dan keempat dari prosedur analisis kontrastif. Ada dua dasar analisis kontrastif psikologi, yaitu pembelajaran asosiasi dan teori stimulasi respon (Nur, 2016). Kata asosiative learning atau belajar asosiatif terjadi jika terdapat keterkaitan atau pergaulan antara dua hal. Dengan kata lain, bahwa analisis kontrastif merupakan suatu konsep yang berfungsi dalam pembelajaran bahasa agar lebih efisien dan efektif (Misdawati, 2019). Analisis kontrastif memiliki tahapan tertentu yang disebut metode analisis kontrastif.

Langkah-langkah metode analisis kontrastif tersirat atau dibayangkan dalam definisi kontrastif berikutnya. Analisis kontrastif memiliki empat langkah untuk membandingkan struktur bahasa 
pertama dan bahasa kedua untuk memprediksi kesulitan belajar dan kesalahan bahasa, memilih bahan ajar, dan menentukan cara penyajian materi dengan benar dalam bahasa kedua agar lebih efisien dan efektif. Berdasarkan definisi analisis kontrastif di atas, maka dapat diidentifikasi empat tahapan dalam metode analisis kontrastif, yaitu:

Langkah pertama, membandingkan struktur bahasa ibu siswa dengan bahasa kedua yang akan dipelajari siswa. Melalui komparasi dapat diketahui perbedaan antara struktur lidah dan bahasa kedua.

Langkah kedua, berdasarkan perbedaan struktur antara bahasa ibu dan bahasa kedua, guru dapat memprediksi kesulitan belajar dan kesalahan bahasa yang mungkin terjadi dan dilakukan siswa dalam pembelajaran bahasa kedua.

Langkah ketiga, kesulitan belajar dan kesalahan bahasa yang telah diprediksi sebagai dasar dalam pemilihan penyusunan materi dan pemilihan pemahaman materi pembelajaran.

Langkah keempat, guru memilih metode dalam penyajian bahasa, seperti: (1) imitasi, (2) pengulangan, (3) latihan teratur, (4) penguatan (Nur, 2016). Metode atau cara analisis kontrastif juga mendeskripsikan tentang area analisis kontrastif.

Langkah pertama berkaitan dengan perbandingan dua struktur bahasa. Ini menunjukkan bahwa analisis kontrastif berkaitan dengan kebahasaan. Langkah kedua, ketiga dan keempat berkaitan dengan kesulitan belajar. Pembelajaran bahasa, pemilihan dan penyusunan materi serta metode penyajian materi pembelajaran bahasa kedua. Ini membuktikan bahwa analisis kontrastif berkaitan dengan pembelajaran psikologi.

Ada dua dasar analisis kontrastif, yaitu teori linguistik dan teori psikologi. Analisis kontrastif yang dideskripsikan dari kedua metode dasar tersebut menunjukkan secara jelas tentang area analisis kontrastif. Area pertama adalah perbandingan dua bahasa yaitu bahasa ibu siswa dan bahasa kedua yang akan dipelajari oleh siswa. Perbandingan ini dapat dilakukan pada setiap sistem bahasa, seperti sistem fonologi, sistem morfologi, sistem sintaksis, sistem semantik, atau sistem penggunaan bahasa. Area kedua berkaitan dengan prediksi kesulitan belajar dan kesalahan bahasa yang mungkin dihadapi siswa dalam belajar bahasa kedua. Area ketiga berkaitan dengan pembelajaran, pemilihan, pengaturan dan tekanan materi. Susunan dasar kesulitan belajar dan kesalahan bahasa yang dihadapi siswa. Bidang keempat berkaitan dengan metode dalam penyajian materi pembelajaran bahasa.

Salah satu proses morfologi dalam bahasa khususnya bahasa Jawa dan bahasa Indonesia adalah proses afiksasi. Proses ini merupakan proses mengubah kata menjadi kata yang kompleks (Amelia, Krisanjaya \& An- 
war, 2018). Selain itu, proses afiksasi dalam bahasa terjadi untuk menghasilkan seperti konjungsi verbal (transitif aktif, intransitif aktif, pasif, pasif tak terkendali, objek lokatif, objek kausatif, objek manfaat, dan lainlain). Amelia, Krisanjaya \& Anwar (2018) menyatakan pada proses afiksasi adalah morfem yang diletakkan pada morfem dasar muncul jika diletakkan pada morfem lain. Maka, proses afiksasi adalah proses penambahan pada kata-kata dan dapat berupa inisial, tengah, posisi akhir atau kombinasi keduanya-membentuk kata baru, artinya kata pertama. Afiks dapat dibedakan menjadi beberapa macam. Terdapat tiga macam afiks yaitu prefiks, sufiks, dan konfiks (Hardyanti, dkk. 2017).

Tabel 4. Jenis Afiksasi

\begin{tabular}{ll}
\hline No & \multicolumn{1}{c}{ Jenis Afikasi } \\
\hline 1 & $\begin{array}{l}\text { preffix, adalah imbuhan yang diletakkan } \\
\text { sebelum root, stem atau kata dasar. }\end{array}$ \\
\hline 2 & $\begin{array}{l}\text { suffix adalah imbuhan yang diletakkan } \\
\text { setelah akar, akar atau kata dasar. }\end{array}$ \\
\hline 3 & $\begin{array}{l}\text { conffix adalah imbuhan yang } \\
\text { menambahkan awal dan akhir kata. }\end{array}$ \\
\hline
\end{tabular}

Afiks sebagai morfem terdiri

dari dua kelompok yaitu morfem infleksi dan morfem turunan (Munandar, 2016). Kedua morfem tersebut membentuk kata dengan cara yang berbeda (Mustaqim \& Hanye, 2018). Morfem turunan membentuk kata dan mengubah kata dasarnya serta mengubah kelas kata dari kata dasar. Berbeda dengan morfem turunan, morfem infleksi membentuk kata tanpa mengubah kelas kata dari kata dasarnya (Rumilah \& Cahyani, 2020).

\section{METODE}

Penelitian ini menggunakan metode deskriptif kualitatif sebagai proses data penelitian. Dengan pemahaman tersebut maka penelitian ini mendeskripsikan tentang data deskriptif untuk menyampaikan data hasil penelitian. Peneliti menggunakan pendekatan kualitatif yang menyajikan data deskriptif yaitu pernyataan atau terjemahan dari bahasa asli ke bahasa tujuan atau dari bahasa tujuan ke bahasa asli ( Nalendra, 2015).

Sumber data penelitian ini terbagi menjadi dua, yaitu sumber data substantif dan sumber data lokal. Sumber data substantif adalah data yang terdiri dari pernyataan representasi. Sumber data lokal artinya sumber data yang merupakan data lingual asli biasa disebut nara sumber (Zaim, 2014). Peneliti menggunakan sumber data bahasa Jawa yang digunakan oleh penutur masyarakat di Madiun, sedangkan bahasa Indonesia yang dijadikan contoh adalah bahasa Indonesia baku. Kedua bahasa tersebut biasanya digunakan secara lisan atau tulisan. Komunikasi lisan misalnya radio dan $\mathrm{TV}$, sedangkan komunikasi tulis adalah koran, majalah, buku cerita.

Untuk menganalisis data, peneliti menggunakan metode analisis konstratif untuk menganalisis bahasa Jawa yang digunakan oleh penutur 
masyarakat Madiun dengan bahasa Indonesia sebagai bahasa pembanding. Metode analisis ini digunakan peneliti bertujuan untuk menunjukkan persamaan dan perbedaan antara bahasa-bahasa atau dialek-dialek, untuk mencari prinsip yang dapat diterapkan, untuk masalah yang praktis seputar pengajaran bahasa dan dalam dunia penerjemahan (Hermanto, 2015).

Metode penelitian ini adalah mengumpulkan data secara objektif kemudian menyusun data berdasarkan kategori. Setelah menyusun data, akan dijelaskan dan dianalisis. Pengumpulan data, dapat dijelaskan sebagai berikut:

(1) mengidentifikasi afiks data dalam bahasa Jawa dan bahasa Indonesia;

(2) menganalisis data;

(3) membuat kesimpulan dari hasil analisis;

(4) membuat prediksi tentang kesulitan-kesulitan yang memudahkan belajar bahasa Indonesia bagi masyarakat yang berlatar belakang bahasa Jawa.

\section{HASIL DAN PEMBAHASAN}

Analisis utama dalam penelitian ini adalah tentang analisis kontrastif bahasa Jawa ngoko yang dituturkan oleh masyarakat Madiun dan bahasa Indonesia berupa verba dan nomina. Proses afiksasi terdiri dari penambahan preffix, suffix dan conffix.

Peneliti menganalisis verba dalam bahasa Jawa dan verba bahasa Indonesia melalui proses afiksasi yang meliputi proses penambahan preffix, conffix dan conffix. Peneliti membandingkan afiks verbal dalam bahasa Jawa ngoko dan afiks verbal dalam bahasa Indonesia. Persamaan dan perbedaan tersebut terdiri dari dua aspek, yaitu kesejajaran afiks verbal dan bentuk dasar yang diletakkan oleh imbuhan tersebut.

Terdapat kemiripan pembentukan verba dengan proses afiksasi antara bahasa Jawa dan bahasa Indonesia dapat dilihat dari persamaan makna yang dibentuk oleh proses afiksasi verbal. Prefiks $N$ yang mengikuti verba dalam bahasa Jawa memiliki arti yaitu proses melakukan sesuatu.

Contoh pengucapan, "Aku arep njupuk buku neng mejo kui."

Dalam contoh di atas, pengertian njupuk adalah proses mengerjakan sesuatu. Kata ini diambil dari kata jupuk yang artinya ambil. Proses yang sama dalam proses afiksasi verbal dalam bahasa Indonesia. Preffix $N$ memiliki arti yang sama dengan afiksyaitu melakukan pemrosesan sesuatu.

Contoh, "Aku mau mengambil buku di atas meja itu."

Kata mengambil terbentuk dari kata ambil yang artinya sama dengan kata njupuk dalam bahasa Jawa. Selain itu preffix $N$, prefiks dalam bahasa Jawa memiliki makna yang sejajar dengan verbal dalam bahasa Indonesia. Prefiks $d i$ - yang dituangkan dalam bahasa Jawa merupakan bentuk verbal pasif. Prefiks ini memiliki arti paralel dengan prefiks di- dalam bahasa Indonesia. Bentuk prefiks ini memiliki arti melakukan 
sesuatu. Hal tersebut terlihat dari subjek yang melakukan sesuatu dengan sengaja.

Contoh, "duite digowo Budi"

Kata digowo dalam pernyataan tersebut merupakan kalimat pasif. Ini sama dengan prefiks $d i$ - dalam bahasa lisan Indonesia.

Contoh, "uangnya dibawa Budi"

Kedua pernyataan tersebut merupakan kalimat pasif artinya melakukan sesuatu yang sengaja dilakukan oleh subjek.

Selain arti, sufiks $-n e,-e n$, tidak ada kalimat perintah bentuk. Sebagai contoh:

(1) Tukokne

Saiki tukokne adikmu permen!

(2) Wacanen

Wacanen surat kui saiki!

(3) Sadhuken

Ndang sadhuken bal kui!

(4) Tangikno

Tangikno bapakmu saiki!

Empat pernyataan di atas berarti kalimat perintah. Bentuk sufiks memiliki makna sufiks paralel dalam bahasa Indonesia yaitu "lah." Kedua sufiks tersebut memiliki arti paralel seperti kalimatnya, contoh:

(1) Belikan

Belikan adikmu permen!

(2) Bacalah

Bacalah surat ini!

(3) Tendanglah

Tendanglah bola itu!

(4) Bangunkan

Bangunkan ayahmu sekarang!
Selain contoh persamaan perumpamaan, bahasa Jawa ngoko memiliki imbuhan yang tidak memiliki perumpamaan dalam bahasa Indonesia disebut prefiks tak-.

(1) tak gowo

(2) tak waca

Awalan tak- diterjemahkan menjadi klausa. Banyak pembicara melakukan kesalahan dalam berbicara. Mereka mencampurkan imbuhan takdalam bahasa Jawa dengan kata kerja dalam bahasa Indonesia secara tidak sengaja.

Contoh:

Mie ayam ini tak makan sampai habis

Seharusnya menjadi:

Mie ayam ini kumakan sampai habis

Penggunaan afiks tak- mudah ditemukan dalam ungkapan lisan. Kesalahan terjadi karena bahasa Jawa adalah bahasa ibu jadi akan bingung menggunakan bahasa Indonesia.

Selain itu, imbuhan ke- dalam bahasa Indonesia memiliki arti yang berbeda dalam bahasa Indonesia. Pembubuhan ke- dalam bahasa Jawa digabungkan dengan kata dasar konsonan tidak akan ada perubahan, seperti contoh:

Kegowo

Kedemok

Kesaduk

Ini bisa disejajarkan dengan prefiks ter- dalam bahasa Indonesia. Prefiks ter- dalam bahasa Indonesia tidak akan ada perubahan jika digabungkan dengan konsonan atau vokal dasar. 
Kegowo $=$ terbawa

Kedemok $=$ tersentuh

Kesaduk $=$ tertendang

Perbedaan, prefiks $k e$ dalam bahasa Indonesia memiliki alomorf, yaitu $/ k /$ atau $/ k e k /$. Kedua alomorf tersebut terjadi jika prefiks $k e$ memenuhi kata dasar vokal.

Atem 'pukul' kantem

Entup 'sengat' kentup

Olu 'telan' kolu

Sedangkan dalam bahasa Indonesia prefiks ter- tidak memiliki alomorf jika digabung dengan kata dasar vokal tidak akan ada perubahan. Biasanya prefiks verbal kememengaruhi penutur yang berlatar belakang bahasa Jawa sebagai bahasa ibu. Kesalahan-kesalahan tersebut beberapa kali terjadi tidak hanya dalam tulisan tetapi juga ucapan lisan seperti kepukul, keselip, kemakan. Jadi, guru bahasa Indonesia perlu menjelaskan verbal pasif menggunakan prefiks ter-

Afiks $N$ juga memiliki perumpamaan dalam bahasa Indonesia berupa prefiks me, akan diperkecil jika digabungkan dengan kata dasar yang diawali huruf ' $C$ '.

Contoh:

Cakot $=$ nyakot

Cangking $=$ nyangking

Pengurangan imbuhan $N$ yang digabungkan dengan kata dasar yang diawali dengan ' $C$ ' akan memengaruhi penutur yang berlatar belakang bahasa Jawa sebagai bahasa lain.

Contoh:

Ibu sedang menyuci baju
Kesalahan yang terjadi karena imbuhan 'saya' sebagai perumpamaan imbuhan $N$ dalam bahasa Jawa, tidak berkurang jika digabungkan dengan kata dasar yang dimulai dari $C$. Guru harus menjelaskan prefiks 'saya' itu dalam Bahasa Indonesia akan berkurang jika dibentuk dari kata dasar yang diawali dengan konsonan $k, t, s, p$. Jadi, baju ibu sedang menyuci harus digunakan sebagai baju basmi.

Dalam penelitian ini peneliti hanya membahas tentang proses afiksasi nominal polimorfemik. Berdasarkan pengertian dan bentuknya, nominal bahasa Jawa dapat dibandingkan dengan bahasa Indonesia nominal. Afiks $p i-$, -an, pi-an dan $p a$ memiliki bentuk imbuhan paralelisme dalam bahasa Indonesia, seperti pe $(N)$, ...- an, per -... an, ke ... an, dan -an. Bentuk dan makna kesejajaran dapat dilihat pada imbuhan pi ... an dalam bahasa Jawa dan imbuhan pe ... an dalam bahasa Indonesia. Misalnya, kata 'pirampungan' dan kata 'penyelesaian' afiks pi ... an dan pe ... an adalah paralelisme artinya.

Dalam proses pembelajaran dwilingual bahasa daerah khususnya pembelajaran bahasa Jawa ngoko dengan dialek Madiunan dengan bahasa Indonesia, pengajar harus memperhatikan keterbatasan bahasa Indonesia yang tidak dapat diakomodasikan oleh bahasa Indonesia. Seperti perbedaan bentuk afiks dalam bahasa Jawa dan bahasa Indonesia, kata benda bahasa Jawa 
tidak dapat diterjemahkan ke dalam bahasa Indonesia. Jadi, dalam penerjemahan membutuhkan kata keterangan berupa frase atau kata-kata yang kompleks karena tidak memiliki kesejajaran dalam bahasa Indonesia. Misalnya:

(1) Pangendhang $=$... (tidak memiliki padanan kata dalam Bahasa Indonesia)

(2) Pambarep $=$... ...( tidak memiliki padanan kata dalam Bahasa Indonesia)

(3) Pakethik $=$... ...( tidak memiliki padanan kata dalam Bahasa Indonesia)

\section{SIMPULAN}

Afiks dalam bahasa Jawa memiliki beberapa persamaan dan perbedaan dengan afiks dalam bahasa Indonesia. Selain itu bentuk dasar bahasa Jawa dan bahasa Indonesia memiliki bentuk yang sama. Persamaan dan perbedaan tersebut terdiri dari dua aspek yaitu kesejajaran bentuk afiks dan kesejajaran makna yang dilampirkan oleh afiks ini. Misalnya, kata 'pirampungan' dengan 'penyelesaian'. Paralelisme pi ... an dengan per ... an adalah paralelisme dalam arti kedua imbuhan.

Materi kontras dalam proses afiksasi merupakan kombinasi bunyi vokal dalam bahasa Indonesia yang tidak akan pernah terjadi. Seperti contoh kata 'cangking' = 'nyangking' $(N$ + cangking). Afiks reduksi $N$ yang digabungkan dengan kata dasar yang diawali huruf $C$ akan memengaruhi penutur berlatar belakang bahasa Jawa sebagai bahasa ibu. Hal itu terlihat pada kalimat "ibu sedang mempersiapkan baju." Selain itu, kontras juga terjadi pada penambahan proses suara, kehilangan suara. Misalnya, cokot 'gigit' nyakot menggigit.

Selain itu, bunyi tambah dan hilang, perbedaan imbuhan dalam bahasa Jawa dan bahasa Indonesia adalah akibat dari imbuhan yang tidak ada perumpamaannya dalam bahasa Indonesia. Misalnya, imbuhan tak dalam bahasa Jawa adalah orang pertama tunggal pada imbuhan bahasa Indonesia yang dijelaskan dalam dua kata. Contoh: "buku ini tak baca", menjadi "buku ini saya baca."

Lebih lanjut, bentuk imbuhan $p a-$ at $N$ dalam bahasa Jawa bukan perumpamaan dalam bahasa Indonesia, sehingga dalam penerjemahan membutuhkan kata keterangan berupa frase atau kata-kata yang kompleks, karena tidak ada paralelisme dalam bahasa Indonesia, misalnya: kata pangendhang harus dijelaskan sebagai orang yang menabuh kendang atau pambarep 'anak pertama dalam keluarga'.

\section{REFERENSI}

Amelia, N., Krisanjaya \& Anwar, M. (2018). Afiksasi pada Karangan Anak di SDN Jatiwaringin 1: Suatu Kajian Berdasarkan Pemerolehan Bahasa. Arkhais, 9 (1), 1-9. 
Ekapartiwi, A. S. (2009). Kontrastif Fonem Tunggal Bahasa Indonesia dan Mandarin (Sebuah Studi Analisis Kontrastif Bahasa). LITE: Jurnal Bahasa, Sastra, dan Budaya, 5 (2).

Hardyanti, S., Wagiran, \& Utami, S. P. T. (2017). Perbandingan Afiks Pembentuk Verba Bahasa Indonesia dan Bahasa Jawa. Jurnal Sastra Indonesia, 6 (1), 34-40.

Hasanah, E., Sofyan, A., Indonesia, J. S., Sastra, F., \& Jember, U. (2015). Jember dan Bahasa Jawa Standar, 1 (1), 1-11.

Hermanto, A. B. (2015). Analisis Kontrastif Afiksasi Verba Bahasa Jawa dengan Bahasa Indonesia. Medan Makna, 8 (1), 1-12.

Kurniawan, P.T. (2013). Analisis Fonologi dan Leksikologi Bahasa Jawa di Desa Pakem Kecamatan Gebang Kabupaten Purworejo. Jurnal Prodi Bahasa dan Sastra Jawa, 2 (4), 71-76.

Kementerian Pendidikan dan Kebudayaan. (2019). Statistik Kebahasaan. Jakarta: Kemendikbud.

Kusumastuti, D. (2017). Analisis Kontrastif Kopula Bahasa Indonesia dengan Bahasa Inggris. Khazanah Pendidikan, 10 (2).

Mijianti, Y. (2017). Peran Bahasa Jawa dan Bahasa Melayu untuk Bahasa Indonesia. Belajar Bahasa: Jurnal Ilmiah Program Studi Pendidikan Bahasa dan Sastra Indonesia, 2 (1), 114-125.

Misdawati, M. (2019). Analisis Kontrastif dalam Pembelajaran Bahasa. A Jamiy: Jurnal Bahasa dan Sastra Arab, 8 (1), 53.
Muhassin, M. (2014). Telaah Linguistik Interdisipliner dalam Makrolinguistik. English Education: Jurnal Tadris Bahasa Inggris, 6 (1), 1-22.

Munandar, Y. (2016). Afiks Pembentuk Verba Bahasa Sunda. Jurnal Humanika, 16 (1), 1-25.

Mustaqim, N., Hanye, P. \& Seli. S. (2018). Morfologi Bahasa Dayak Pompakng. Jurnal Pendidikan dan Pembelajaran Khatulistiwa, 7 (4).

Nalendra, A.R.A (2015). Pelanggaran Maksim Percakapan dalam Materi Stand Up Comedy. Wanastra, 7 (1), 1-9.

Nur, T. (2016). Analisis Kontrastif Dalam Studi Bahasa. Arabi: Journal of Arabic Studies, 1 (2), 64.

Paryono, Y. (2014). Sistem Kata Ulang Bahasa Jawa Subdialek Madiun. Madah: Jurnal Bahasa dan Sastra, 5 (2), 243-252.

Rumilah, S., \& Cahyani, I. (2020). Struktur Bahasa, Pembentukan Kata dan Morfem sebagai Proses Morfemis dan Morfofonemik dalam Bahasa Indonesia. Jurnal Pendidikan Bahasa Indonesia, 8, 70-87.

Sanga, F. (2008). Analisis Kontrastif Mengatasi Kesulitan Guru Bahasa di Provinsi Nusa Tenggara Timur. Linguistika, 15 (28), 1-25.

Suharyo, S. (2018). Nasib Bahasa Jawa dan Bahasa Indonesia dalam Pandangan dan Sikap Bahasa Generasi Muda Jawa. Nusa: Jurnal Ilmu Bahasa dan Sastra, 13 (2), 244.

Sukarto, K. A. (2010). Analisis Kontrastif Sistem Morfemis 
Nomina Bahasa Jawa-Indonesia.

Sawomanila, 1 (4), 91-100.

Ula, M., Santoso, A. B., \& Winarsih, E. (2020). Penggunaan Bahasa Pembawa Acara Pernikahan di Wilayah Madiun. Widyabastra, 8 (1), 48-59.

Zaim, M. (2014). Metode Penelitian Bahasa: Pendekatan Struktural. Metode Penelitian Bahasa: Pendekatan Struktural, 1-123. 